\title{
COMPARISON BETWEEN MIXED LIQUORS OF TWO SIDE-STREAM MEMBRANE BIOREACTORS TREATING WASTEWATERS FROM WASTE MANAGEMENT PLANTS WITH HIGH AND LOW SOLIDS ANAEROBIC DIGESTION
}

\author{
E. Zuriaga-Agustí ${ }^{1 *}$, J.A. Mendoza-Roca ${ }^{1}$, A. Bes-Piá ${ }^{1}$, J.L. Alonso-Molina ${ }^{2}$, F. \\ Muñagorri-Mañueco ${ }^{3}$, G. Ortiz-Villalobos ${ }^{3}$, E. Fernández-Giménez ${ }^{3}$ \\ ${ }^{1}$ Instituto de Seguridad Industrial, Radiofísica y Medioambiental, Universitat Politècnica de \\ València. Camino de Vera s/n 46022 Valencia (Spain); e-mail*: elzuag@etsii.upv.es \\ ${ }^{2}$ Instituto Ingeniería del Agua y Medio Ambiente, Universitat Politècnica de València, Camino \\ de Vera s/n 46022 Valencia (Spain) \\ ${ }^{3}$ URBASER, Camino de las Hormigueras 171, 28031 Madrid (Spain)
}

\begin{abstract}
In the last years, biological treatment plants for the previously separated organic fraction from municipal solid wastes (OFMSW) have gained importance. In these processes a liquid effluent (liquid fraction from the digestate and leachate from composting piles), which has to be treated previously to its discharge, is produced. In this paper, the characteristics of the mixed liquor from two full-scale membrane bioreactors treating the effluents of two OFMSW treatment plants have been evaluated in view to study their influence on membrane fouling in terms of filterability. For that, the mixed liquor samples have been ultrafiltrated in an UF laboratory plant. Besides, the effect of the influent characteristics to MBRs and the values of the chemical and physical parameters of the mixed liquors on the filterability have been studied. Results showed that the filterability of the mixed liquor was strongly influenced by the soluble microbial products in the mixed liquors and the influent characteristics to MBR. Permeate flux of MBR mixed liquor treating the most polluted wastewater was considerable the lowest (around $20 \mathrm{~L} / \mathrm{m}^{2} \cdot \mathrm{h}$ for some samples), what was explained by viscosity and soluble microbial products concentration higher than those measured in other MBR mixed liquor.
\end{abstract}

Keywords: MBR; leachate; digestate; municipal wastes; anaerobic digestion. 


\section{Introduction}

Municipal waste treatment generates wastewaters that have to be treated before their disposal. In the case of sanitary landfills, the generated liquid effluent is named leachate. Leachates are very pollutants and they are characterized by very high organic matter and ammonium concentrations, among others. Other types of municipal waste treatment plants, which have gained importance in the last years, are the named biomethanation plants, which usually treat the previously separated organic matter fraction from the municipal solid wastes (OFMSW) (Cesaro et al., 2015). These plants consist of a pretreatment stage, an anaerobic digestion (AD) for methane production and a further composting of the solid fraction of the digestate (Tampio et al., 2015). As a result, two types of waste liquid effluents are produced, digestate liquor (liquid fraction from the anaerobically treated waste after being dehydrated) and leachate from the composting piles. Both effluents require treatment before being discharged to a municipal wastewater treatment plant.

Processes for leachate treatment have been summarized by some authors in review papers (Omar and Rohani, 2015; Pokhrel and Viraraghavan, 2004; Renou et al., 2008; Wiszniowski et al., 2006). It can be commented that all the types of wastewater processes (physical, chemical and biological processes) have been used for the leachates management. Because of its high pollution load, high efficient processes or combination of different ones have to be applied.

Membrane bioreactor (MBR) is one of the processes that have gained importance in the leachate treatment. This process has been successfully applied to treat wastewaters with toxic compounds in low concentrations (Boonyaroj et al., 2012; Nghiem et al., 2009; Svojitka et al., 2009). Besides the treated water quality achieved, other advantage of MBRs in comparison with other technologies is the smaller footprint, since high biomass concentration can be maintained in the reactor (Judd, 2011).

Papers about MBR treating leachates have been mainly focused on the quality of the treated water (Ahmed and Lan, 2012; Lin et al., 2012). Ahmed and Lan (2012) also stated that the majority of the published papers related to landfill leachate treatment by MBRs are bench or pilot scale studies. Alvarez-Vazquez et al., 2004 carried out a comparison between the quality of the treated leachate with MBR and with other 
biological techniques. They concluded that MBRs usually offer high COD removal efficiencies for less biodegradable feeds at a much smaller footprint. Campagna et al. (2013) evaluated the size of the organic matter of a landfill leachate and the evolution of these fractions after a MBR and after a further nanofiltration stage. These fractions were related with their removal in the process (Campagna et al., 2013).

Table 1 summarizes the papers of several authors who reported results about the application of MBRs to landfill leachates. MBR size in terms of membrane surface, membrane configuration, leachate characteristics and mixed liquor characteristics have been included. As it can be observed, only little information is available about physicchemical characteristics of the mixed liquor. 
Table 1. Reported data in the literature about MBRs treating landfill leachate

\begin{tabular}{|c|c|c|c|c|}
\hline Author & $\begin{array}{c}\text { Scale } \\
\text { (Membrane } \\
\text { surface) }\end{array}$ & MBR configuration & Leachates characteristics & $\begin{array}{l}\text { Physico-chemical characteristics of } \\
\text { mixed liquor }\end{array}$ \\
\hline $\begin{array}{l}\text { Boonyaroj et al. } \\
\text { (2012) }\end{array}$ & Pilot & Not detailed & $\begin{array}{l}\mathrm{pH}=7.4, \mathrm{COD}=9306 \mathrm{mg} / \mathrm{L}, \quad \mathrm{NH}_{3}-\mathrm{N}=138 \\
\mathrm{mg} / \mathrm{L}, \mathrm{SS}=1240 \mathrm{mg} / \mathrm{L}, \text { conductivity }=23.5 \\
\mathrm{mS} / \mathrm{cm} \text { (average values) }\end{array}$ & $\begin{array}{l}\text { MLSS }=10000-12000 \mathrm{mg} / \mathrm{L} \text {, sludge } \\
\text { volume index }=30-60 \mathrm{~mL} / \mathrm{g}\end{array}$ \\
\hline $\begin{array}{l}\text { Campagna et al. } \\
\text { (2013) }\end{array}$ & $\begin{array}{l}\text { Full scale treating } \\
2000 \mathrm{~m}^{3} / \mathrm{d}\end{array}$ & External (tubular) & $\begin{array}{l}\mathrm{COD}=16360 \mathrm{mg} / \mathrm{L}, \mathrm{NH}_{4}{ }^{+}-\mathrm{N}=2532 \mathrm{mg} / \mathrm{L}, \\
\text { conductivity }=33.9 \mathrm{mS} / \mathrm{cm} \quad \text { (average } \\
\text { values) }\end{array}$ & Data not shown \\
\hline $\begin{array}{l}\text { Canziani et al. } \\
(2006)\end{array}$ & Pilot $\left(0.24 \mathrm{~m}^{2}\right)$ & $\begin{array}{l}\text { External (ceramic } \\
\text { membranes) }\end{array}$ & $\begin{array}{l}\mathrm{COD}=6316 \mathrm{mg} / \mathrm{L}, \mathrm{NH}_{4}{ }^{+}-\mathrm{N}=1497 \mathrm{mg} / \mathrm{L} \\
\text { (average values) }\end{array}$ & $\begin{array}{l}\text { MLSS }=5000-8000 \mathrm{mg} / \mathrm{L}, \mathrm{Y}=0.67 \\
\mathrm{gSS} / \mathrm{gCOD}\end{array}$ \\
\hline $\begin{array}{l}\text { Hasar et al. } \\
(2009)\end{array}$ & $\operatorname{Lab}\left(0.0390 \mathrm{~m}^{2}\right)$ & $\begin{array}{l}\text { Submerged (hollow } \\
\text { fiber) }\end{array}$ & $\begin{array}{l}\mathrm{pH}=6.45-6.50, \mathrm{sCOD}=8500-14200 \\
\mathrm{mg} / \mathrm{L}, \mathrm{NH}_{4}^{+}-\mathrm{N}=1100-2150 \mathrm{mg} / \mathrm{L} \\
\text { Mixed with domestic wastewater before } \\
\text { feeding to MBR }\end{array}$ & $\mathrm{MLSS}=4000-10000 \mathrm{mg} / \mathrm{L}$ \\
\hline $\begin{array}{l}\text { Hashisho et al. } \\
\text { (2016) }\end{array}$ & Lab & $\begin{array}{l}\text { Submerged } \\
\text { (comparison between } \\
\text { hollow fiber and flat } \\
\text { sheet membranes) }\end{array}$ & $\begin{array}{l}\mathrm{pH}=8.43, \mathrm{COD}=5978 \mathrm{mg} / \mathrm{L}, \mathrm{NH}_{4}{ }^{+}-\mathrm{N}= \\
\mathrm{mg} / \mathrm{L}=2464, \mathrm{TN}=2543 \mathrm{mg} / \mathrm{L} \text { (average } \\
\text { values) }\end{array}$ & Data not shown \\
\hline Litas et al. (2012) & Pilot & $\begin{array}{l}\text { Submerged (flat } \\
\text { sheet) }\end{array}$ & $\begin{array}{l}\mathrm{pH}=8.7, \mathrm{COD}=2544 \mathrm{mg} / \mathrm{L}, \mathrm{NH}_{4}^{+}-\mathrm{N}= \\
\mathrm{mg} / \mathrm{L}=269, \mathrm{TN}=388 \mathrm{mg} / \mathrm{L} \text { (average } \\
\text { values). Diluted } 1: 1 \text { with municipal } \\
\text { wastewater }\end{array}$ & $\begin{array}{l}\text { MLSS increasing between } 2000 \text { and } \\
25000 \mathrm{mg} / \mathrm{L}, \% \text { of } \mathrm{VSS}=84-70\end{array}$ \\
\hline
\end{tabular}




\begin{tabular}{|c|c|c|c|c|}
\hline Author & $\begin{array}{c}\text { Scale } \\
\text { (Membrane } \\
\text { surface) }\end{array}$ & MBR configuration & Leachates characteristics & $\begin{array}{l}\text { Physico-chemical characteristics of } \\
\text { mixed liquor }\end{array}$ \\
\hline $\begin{array}{l}\text { Rizkallah et al. } \\
\text { (2013) }\end{array}$ & Pilot $\left(0.929 \mathrm{~m}^{2}\right)$ & $\begin{array}{l}\text { Submerged (hollow } \\
\text { fiber) }\end{array}$ & $\begin{array}{l}\mathrm{pH}=7.26-7.91, \mathrm{COD}=9000-20000 \\
\mathrm{mg} / \mathrm{L}, \mathrm{NH}_{3}-\mathrm{N}=1800-4000 \mathrm{mg} / \mathrm{L} ; \mathrm{TN}= \\
2000-6000 \mathrm{mg} / \mathrm{L}, \mathrm{SS}=625-938 \mathrm{mg} / \mathrm{L}, \\
\mathrm{VSS}=300-500 \mathrm{mg} / \mathrm{L}, \text { conductivity }=38.2 \\
-50.4 \mathrm{mS} / \mathrm{cm}\end{array}$ & Up to $7000 \mathrm{mg} / \mathrm{L}$ of MLVSS \\
\hline $\begin{array}{l}\text { Sanguanpak et al. } \\
\text { (2015) }\end{array}$ & $\operatorname{Lab}\left(0.07 \mathrm{~m}^{2}\right)$ & $\begin{array}{l}\text { Submerged (hollow } \\
\text { fiber) }\end{array}$ & $\mathrm{COD}=5445 \mathrm{mg} / \mathrm{L}$ (average value) & $\begin{array}{l}\text { Zeta potential between }-13 \text { and }-21 \mathrm{mV} \text {, } \\
\mathrm{SMP}_{\mathrm{p}}=98.8-132.2 \mathrm{mg} / \mathrm{L}, \mathrm{SMPc}=24.3- \\
44.6 \mathrm{mg} / \mathrm{L}, \text { eEPS }_{\mathrm{p}}=50.4-68.3 \mathrm{mg} / \mathrm{gSS} \text {, } \\
\text { eEPS }_{\mathrm{c}}=18.4-29.4 \mathrm{mg} / \mathrm{gSS} \text {, unsettled } \mathrm{SS} \\
18-80 \mathrm{mg} / \mathrm{L} \text {, mean floc size }=54-58 \\
\text { microns }^{1}\end{array}$ \\
\hline $\begin{array}{l}\text { Svojitka et al. } \\
\text { (2009) }\end{array}$ & $\begin{array}{l}\text { Lab (inflow rate } \\
\left(0.1 \mathrm{~m}^{2}\right)\end{array}$ & External (tubular) & $\begin{array}{l}\mathrm{pH}=8.5, \mathrm{COD}=2200 \mathrm{mg} / \mathrm{L}, \mathrm{NH}_{4}{ }^{+}-\mathrm{N}=1200 \\
\mathrm{mg} / \mathrm{L} ; \mathrm{TN}=1258 \mathrm{mg} / \mathrm{L}\end{array}$ & $\mathrm{MLSS}=7100-11800 \mathrm{mg} / \mathrm{L}$ \\
\hline
\end{tabular}


The main operating problem for the application of MBRs to leachate treatment is membrane fouling. In general terms, this phenomenon is the main drawback of MBRs and fouling may be more severe in MBRs treating leachate due to its composition. This phenomenon could make the process unfeasible by increasing the transmembrane pressure (TMP) to achieve a sustainable flux. Membrane fouling mainly depends on membrane module design, wastewater composition, membrane characteristics, operation of the filtration process and operation of the biological process (Khongnakorn et al., 2007; Lyko et al., 2008; Meng et al., 2009). Once the MBR is working, only operating conditions can be modified; thereby the control of the mixed liquor characteristics will be of paramount importance to prevent or reduce the membrane fouling (Lin et al., 2014). According to literature, extracellular polymeric substances (EPS), both extracted from the cell wall of bacteria (eEPS) and soluble microbial products (SMP) are the main responsible for membrane fouling (Ding et al., 2015; Liu et al., 2012; Wang et al., 2009).

This is the reason why they should be analysed and controlled. However, unlike applications of MBR to municipal wastewater, only a few papers about mixed liquor characterization from industrial WWTPs are found. Only Sanguanpak et al., 2015 reported results about the influence of the leachate $\mathrm{pH}$ on EPS generation and consequently on membrane fouling.

Literature also lacks of papers dealing with the treatment of leachate from composting and digestate liquor by MBR technology. Although composition can be in rough outlines very similar to landfill leachates, specific works for effluents from anaerobic digestion (digestate liquor) plus aerobic digestion (leachate) OFMSW are required. Brown et al., 2013, detailed the elimination efficiencies of a great number of compounds in a MBR treating leachate from composting of the OFMSW.

In this paper, the operation of two full-scale MBRs with external membrane configuration (side-stream MBRs) treating effluents from two OFMSW plants is studied from the point of view of the mixed liquor characterization. Comparison is carried out in order to find out the differences in the MBR mixed liquors caused by the different type of process carried out in the OFMSW. Both plants consist of anaerobic digestion plus composting processes. 


\section{Materials and Methods}

\section{$\underline{\text { Full scale MBRs }}$}

Samples were obtained from two full-scale MBRs. MBRs treat the waste effluents from OFMSW plants, specifically from the AD and composting processes.

The difference between both plants is that the $\mathrm{AD}$ process in one plant is carried out by means of a high solids system (Dry-process, i.e. solids concentration higher than $15 \%$ (Li et al., 2011)) and the other one by means of a low solids system (Wet-process, i.e. solids concentration lower than 10\%), Hereafter, MBRs will be referred to as MBR-HS and MBR-LS in order to distinguish them.

For both plants the MBR configuration is the same, i.e. membranes are external and mixed liquor is pumped from the biological reactor to the UF module (MBR recirculated). Membranes are multichannel tubular and the installed active surface is $127 \mathrm{~m}^{2}$ and $72 \mathrm{~m}^{2}$ in MBR-LS and MBR-HS, respectively. Biological reactor consists of one anoxic tank, two aerobic tanks and a final tank that can be operated aerobically or anoxically depending of the nitrogen removal efficiencies. Therefore, both plants were designed to eliminate both organic matter and nitrogen.

\section{$\underline{\text { Sampling }}$}

Six samples, one per month, were taken from both MBRs. Samples were maintained refrigerated at $4^{\circ} \mathrm{C}$ until they were processed (the day after the collection). Sample points were the influent to MBRs streams and the mixed liquor that was pumped to the membranes from the last tank of the reactor.

\section{Analyses of the influent}

The following characterization parameters were measured: $\mathrm{pH}$, conductivity, total nitrogen (TN), soluble total nitrogen (sTN), ammonium nitrogen $\left(\mathrm{NH}_{4}{ }^{+}-\mathrm{N}\right)$, total COD (tCOD), soluble COD (sCOD) and suspended solids (SS).

$\mathrm{pH}$ and conductivity were respectively measured with $\mathrm{pH}-$ Meter (GLP-21+) and ECMeter (GLP-31+) from CRISON (Spain). TN, sTN, $\mathrm{NH}_{4}{ }^{+}-\mathrm{N}$, tCOD and sCOD were determined spectrophotometrically by means of standard cell tests from Merck. Samples 
had to be diluted so that no interferences were produced by salinity and colour. Suspended solids were measured in duplicate according to APHA, 2005.

\section{Ultrafiltration of the mixed liquor sample in laboratory}

In order to compare the sludge filterability, $5 \mathrm{~L}$ of mixed liquor of each MBR were ultrafiltrated in a laboratory plant equipped with a Rayflow 100 membrane module, (Orelis, France) containing a flat-sheet membrane with an active surface of $100 \mathrm{~cm}^{2}$. Figure 1 represents the flowchart of the laboratory plant. The membrane used in every test was a $150 \mathrm{kDa}$ hydrophilic polyethersulfone membrane from Microdyn Nadir, membrane characteristics are shown in Table 2. A new membrane was used for each experiment, so that permeate flow were not influenced by the residual membrane fouling from the earlier test.

Table 2: Membrane characteristics and filtration test conditions

\begin{tabular}{cc}
\hline Active surface area $\left(\mathrm{cm}^{2}\right)$ & $100 \mathrm{~cm}^{2}$ \\
Operating pressure (bar) & $0-1 \mathrm{bar}$ \\
Crossflow velocity $(\mathrm{m} / \mathrm{s})$ & $2 \mathrm{~m} / \mathrm{s}$ \\
Feed flow rate $(\mathrm{L} / \mathrm{h})$ & $300 \mathrm{~L} / \mathrm{h}$ \\
Membrane material & Polyethersulfone \\
hydrophilic $(\mathrm{PES})$ \\
Membrane pore size & $0.04 \mu \mathrm{m}$ \\
MWCO & $150 \mathrm{kDa}$ \\
\hline
\end{tabular}




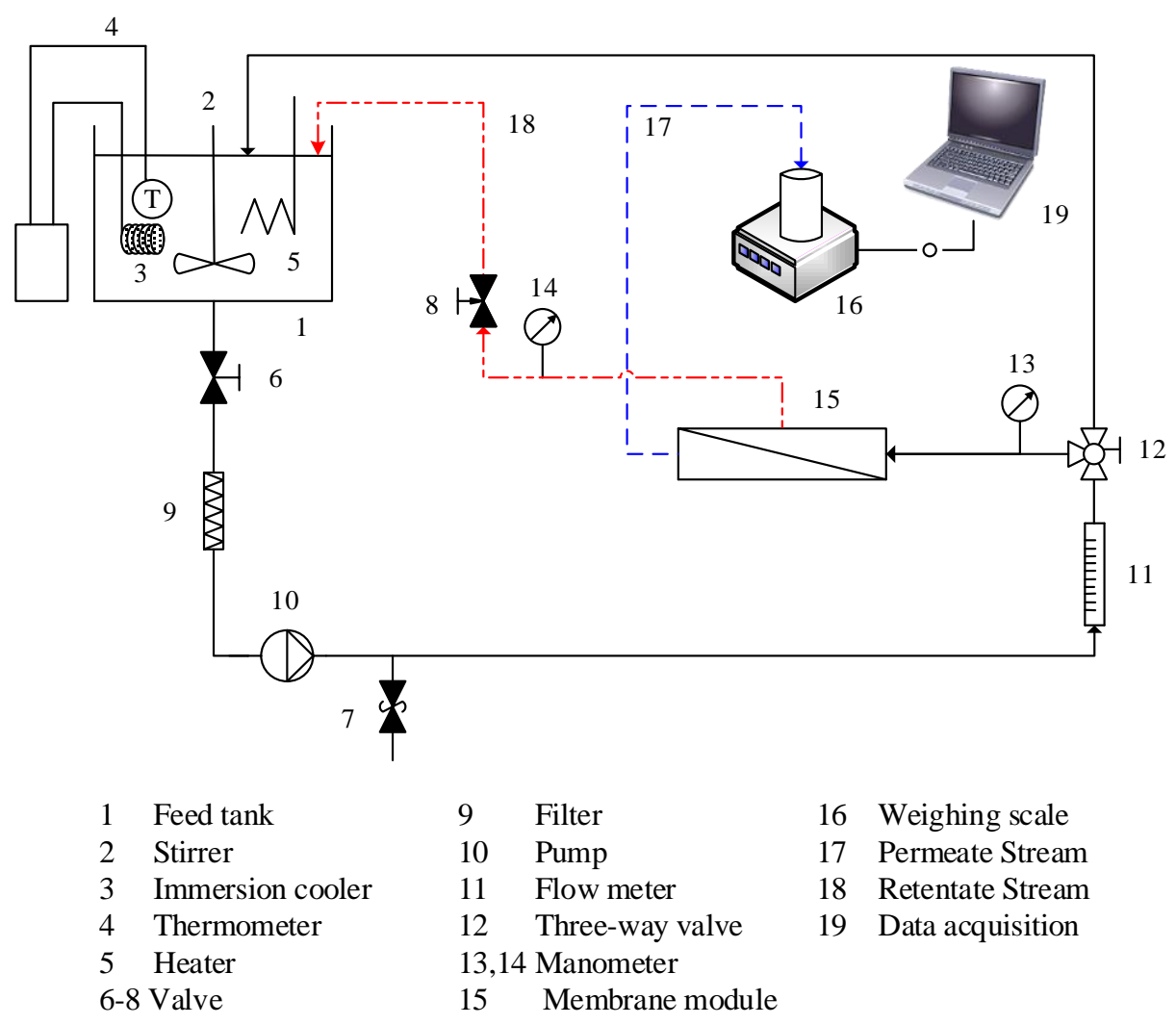

Figure 1: Ultrafiltration laboratory plant scheme (150 kDa membrane)

Tests were carried out at the following operating conditions: 1 bar of TMP, $25^{\circ} \mathrm{C}$ of temperature (T) and $2 \mathrm{~m} / \mathrm{s}$ of crossflow velocity by means of a variable speed pump. The duration of each test was the necessary to reach the steady state (constant flux). The minimum duration considered was 2 hours. Experiments were carried out in total recycle mode of filtration, where both retentate and permeate streams were continuously recirculated into the feed tank. The permeate flux $\left(J_{p}\right)$ was gravimetrically measured with an electronic weighing scale (KERN KB 2400-2N, 0.01 g accuracy, Germany) connected to a computer with a data acquisition software (Balance Connection SCD$4.0, \operatorname{Kern}^{\circledR}$ ). Data were recorded in the computer each minute. The permeate flux was monitored throughout the UF experiments according to Eq. (1), in order to determine the flux decline.

$$
J_{p}=\frac{V_{p}}{A \cdot t}
$$

Where $\mathrm{Jp}$ is the permeate flux $\left(\mathrm{L} / \mathrm{m}^{2} \cdot \mathrm{h}\right), \mathrm{Vp}$ is the permeate volume $(\mathrm{L}), \mathrm{A}$ is the effective membrane area $\left(\mathrm{m}^{2}\right)$ and $\mathrm{t}$ is the sampling time $(\mathrm{h})$. 


\section{Calculation of membrane filtration resistances}

Total filtration resistance $\left(\mathrm{R}_{\mathrm{T}}\right)$ has been calculated according to Eq. 2 (Bae and Tak, 2005). $\mathrm{R}_{\mathrm{T}}\left(\mathrm{m}^{-1}\right)$ can be expressed as the sum of the resistances caused by the membrane $\left(\mathrm{R}_{\mathrm{m}}\right)$, the resistance that can be eliminated after rinsing $\left(\mathrm{R}_{\text {rev }}\right)$ and the remaining resistance $\left(\mathrm{R}_{\text {irrev }}\right)$.

$$
R_{t}=\frac{T M P}{\mu \cdot J_{p}}
$$

Where TMP is the transmembrane pressure $(\mathrm{Pa}), \mu$ is the viscosity $(\mathrm{Pa} \cdot \mathrm{s})$ and $\mathrm{J}_{\mathrm{p}}$ is the permeate flux by filtrating activated sludge at the steady state $\left(\mathrm{L} / \mathrm{m}^{2} \cdot \mathrm{h}\right)$.

Irreversible resistance ( $\mathrm{R}_{\text {irrev }}$ ) was calculated according to Eq. 3.

$$
R_{\text {irrev }}=\frac{T M P}{\mu \cdot J_{w}}-R_{m}
$$

Where $J_{w}$ is the membrane flux after water rinsing and $R_{m}$ is the membrane resistance. Reversible resistance $\left(\mathrm{R}_{\text {rev }}\right)$ was calculated applying Eq. 4.

$$
R_{\text {rev }}=R_{t}-R_{\text {irrev }}-R_{m}
$$

\section{Mixed liquor characterization}

The characterization of the mixed liquor was physical and chemical.

The physical parameters measured were mixed liquor suspended solids (MLSS), mixed liquor volatile suspended solids (MLVSS), capillary suction time (CST) and viscosity.

MLSS and MLVSS were analysed according to APHA (APHA, 2005). Capillary suction time (CST) was measured with the equipment Triton (304M model, United Kingdom). Due to the high MLSS concentration, samples were diluted with deionized water. Viscosity was measured with a rheometer from Haake RheoStress 1 (Thermo, Germany), equipped with concentric cylinder (Z34 DIN sensor) and operated at constant temperature $\left(20^{\circ} \mathrm{C}\right)$. Shear rate $(\dot{\gamma})$ was increased and decreased since 0 to 800 $\mathrm{s}^{-1}$, in order to study eventual thixotropy. 
The chemical characterization of the mixed liquor samples was performed by measuring both SMP and eEPS. SMP were determined after centrifuging at $12000 \mathrm{xg}$ and filtering (0.45 microns). For eEPS extraction the cation exchange resin (CER) method (Frølund et al., 1996) was applied. In order to avoid interferences between the activated sludge and the analytical methods, sample dilutions were carried out until achieving $2 \mathrm{gVSS} / \mathrm{L}$ (Ras et al., 2008). In both, SMP and eEPS, proteins (by BCA method) and carbohydrates (by Anthrone method) were analysed. Bovine serum albumin (BSA) (Sigma-Aldrich) and glucose (Panreac) were used as the protein and carbohydrate standards.

\section{$\underline{\text { Respirometry test }}$}

Respirometry tests were carried out in a BM-Advance analyser from SURCIS (Spain). Respirometry is based on the oxygen consumption by the microorganisms from the activated sludge. The reactor vessel was filled with $1 \mathrm{~L}$ of MBR activated sludge from MBR-LS or MBR-HS depending on the experiment to be held. The activated sludge was previously aerated during $24 \mathrm{~h}$ to obtain endogenous conditions in the biomass. A dynamic experiment was performed by continuous stirring, aeration and recirculation between both sides of the vessel by means of a peristaltic pump, where the dissolved oxygen was continuously measured. Temperature was kept constant at $22^{\circ} \mathrm{C}$ during the experiment through a Peltier cooler module. The heterotrophic biomass yield coefficient $\left(\mathrm{Y}_{\mathrm{H}}\right)$ was calculated by Eq. 6.

$$
Y_{H}=1-\frac{O C}{C O D_{\text {sodium acetate }}}
$$

Where OC is the oxygen consumed by the microorganisms to biodegrade a substrate. To determine the OC a dynamic respirometry test was performed by adding a sodium acetate solution of $400 \mathrm{mg} / \mathrm{L}(\mathrm{COD}=300 \mathrm{mg} / \mathrm{L})$. In order to determine the COD fractionation, different dynamic tests were carried out by adding in the vessel $15 \mathrm{~mL}$ of influent wastewater (for the total COD) and influent wastewater filtered by $0.45 \mu \mathrm{m}$ (for the soluble fraction, rapidly biodegradable COD) to study their biodegradation. 
Fluorescence in situ hybridization (FISH) and microscopic observation

Identification and estimation of filament abundance within the phylum Bacteroidetes were performed by applying SAP-309 probe (25\% formamide) targeting the family Saprospiraceae (Schauer and Hahn, 2005). Samples were fixed in $4 \%$ paraformaldehyde at $4{ }^{\circ} \mathrm{C}$. The fixed biomass was washed three times with phosphatebuffered saline (PBS), and re-suspended in a 1:1 (v/v) volume of PBS and absolute ethanol and then stored at $-20{ }^{\circ} \mathrm{C}$. The fixed samples were immobilized on gelatincoated glass slides, air-dried, and consecutively dehydrated in 50\%, 80\% and absolute ethanol. Subsequently, $9 \mu \mathrm{l}$ of hybridization solution was mixed with $1 \mu \mathrm{l}(50 \mathrm{ng})$ of Tamra-labeled SAP-309 probe. Hybridization buffer and probe were applied to the slide and incubated at $46{ }^{\circ} \mathrm{C}$ for 2 hours. After hybridization, the slides were incubated in the washing buffer for $15 \mathrm{~min}$ in a $48{ }^{\circ} \mathrm{C}$ water bath (Rossetti et al., 2006). The slides were incubated with a 4',6'-diamidino-2-phenylindole (DAPI) solution (final concentration 1 $\mu \mathrm{g} / \mathrm{ml}$ ) at $4{ }^{\circ} \mathrm{C}$ for $15 \mathrm{~min}$. Microscopic observation was performed using an epifluorescence microscope (Olympus BX50, Japan, equipped with a CCD camera (Olympus DP12, Japan).

\section{Results}

\section{Influent wastewater and permeate characterization}

Table 3 shows the characterization of the influent wastewaters to MBRs. Average values of the 6 samples and standard deviations have been included. 
Table 3. Characterization of the influent wastewaters to MBRs $(n=6)$

\begin{tabular}{ccc}
\hline & MBR-LS & MBR-HS \\
\hline $\mathrm{pH}$ & $7.99 \pm 0.10$ & $7.99 \pm 0.10$ \\
Conductivity $(\mathrm{mS} / \mathrm{cm})$ & $16.26 \pm 6.97$ & $40.13 \pm 4.65$ \\
$\mathrm{SS}(\mathrm{mg} / \mathrm{L})$ & $4401 \pm 1812$ & $12940 \pm 1301$ \\
$\mathrm{tCOD}(\mathrm{mg} / \mathrm{L})$ & $9430 \pm 5944$ & $32910 \pm 7106$ \\
$\mathrm{sCOD}(\mathrm{mg} / \mathrm{L})$ & $3140 \pm 1262$ & $20927 \pm 7635$ \\
$\mathrm{TN}(\mathrm{mg} / \mathrm{L})$ & $1879 \pm 990$ & $6267 \pm 2666$ \\
$\mathrm{sTN}(\mathrm{mg} / \mathrm{L})$ & $790 \pm 320$ & $4890 \pm 406$ \\
$\mathrm{NH}_{4}-\mathrm{N}(\mathrm{mg} / \mathrm{L})$ & $767 \pm 324$ & $3990 \pm 410$ \\
\hline
\end{tabular}

Differences between both wastewaters are considerable except for $\mathrm{pH}$ value. Thus, the influent to MBR-HS has a concentration of SS approximately three times higher than the MBR-LS, what is clearly due to the way of carrying out the anaerobic digestion. This also affects to the tCOD and TN values, in such a way that analysis showed almost the same relation between both wastewaters (tCOD and TN are 3.5 and 3.3 times higher in the influent to MBR-HS than in the influent to MBR-LS).

Concerning conductivity, it has to be highlighted that values were much higher in the influent to MBR-HS than in the influent to MBR-LS, though samples in MBR-HS showed less variable values.

In addition, sCOD, sTN and $\mathrm{NH}_{4}{ }^{+}-\mathrm{N}$ of influent to MBR-HS were also much higher than in the influent to MBR-LS. As expected, these values were in concordance with the tCOD and TN obtained for both plants.

In comparison with landfill leachates, the characteristics of MBR-LS are similar to those reported by authors whose works have been summarized in Table 1. However, SS concentrations in the MBR-LS influent were higher than in the landfill leachates. Concerning MBR-HS, concentrations of all measured parameters were higher than those reported for landfill leachates. 
In general terms, it can be assumed that the high SS and COD concentrations in the effluents from the OFMSW treatment plants require a biological process with high biomass concentrations in the reactors and high hydraulic retention times, especially in the case of the plant with high solids anaerobic digestion.

\section{$\underline{\text { Ultrafiltration experiments }}$}

Membrane permeability was measured using deionized water as feed before each UF test. The mean value of the membrane permeability measured was $500 \mathrm{~L} /\left(\mathrm{m}^{2} \cdot \mathrm{h}\right)$. Membrane was discarded if the permeability value measured was $15 \%$ above or below the mean value with the aim that all the tests were comparable.

In Table 4, filtration resistances are shown for each activated sludge sample from both MBRs. As it can be observed, in samples from MBR-HS, the $R_{t}$ was higher than in the MBR-LS ones. This fact is in agreement with the results shown in figure 2.

Table 4: Membrane filtration resistances in the activated sludge from MBR-LS and MBR-HS

\begin{tabular}{ccccccc}
\hline MBR-LS & $\mathrm{S} 1$ & $\mathrm{~S} 2$ & $\mathrm{~S} 3$ & $\mathrm{~S} 4$ & $\mathrm{~S} 5$ & $\mathrm{~S} 6$ \\
\hline $\mathrm{R}_{\mathrm{t}}\left(\mathrm{m}^{-1}\right)$ & $8.01 \mathrm{E}+12$ & $1.15 \mathrm{E}+13$ & $6.50 \mathrm{E}+12$ & $8.77 \mathrm{E}+12$ & $6.93 \mathrm{E}+12$ & $4.04 \mathrm{E}+12$ \\
\hline $\mathrm{R}_{\text {irrev }}\left(\mathrm{m}^{-1}\right)$ & $8.62 \mathrm{E}+11$ & $5.23 \mathrm{E}+11$ & $7.94 \mathrm{E}+11$ & $2.19 \mathrm{E}+12$ & $1.66 \mathrm{E}+12$ & $4.12 \mathrm{E}+11$ \\
\hline $\mathrm{R}_{\text {rev }}\left(\mathrm{m}^{-1}\right)$ & $6.35 \mathrm{E}+12$ & $9.96 \mathrm{E}+12$ & $4.80 \mathrm{E}+12$ & $5.79 \mathrm{E}+12$ & $4.75 \mathrm{E}+12$ & $2.90 \mathrm{E}+12$ \\
\hline $\mathrm{MBR}-\mathrm{HS}$ & $\mathrm{S} 1$ & $\mathrm{~S} 2$ & $\mathrm{~S} 3$ & $\mathrm{~S} 4$ & $\mathrm{~S} 5$ & $\mathrm{~S} 6$ \\
\hline $\mathrm{R}_{\mathrm{t}}\left(\mathrm{m}^{-1}\right)$ & $1.97 \mathrm{E}+13$ & $1.99 \mathrm{E}+13$ & $1.73 \mathrm{E}+13$ & $2.16 \mathrm{E}+13$ & $1.97 \mathrm{E}+13$ & $1.64 \mathrm{E}+13$ \\
\hline $\mathrm{R}_{\text {irrev }}\left(\mathrm{m}^{-1}\right)$ & $9.86 \mathrm{E}+11$ & $8.20 \mathrm{E}+11$ & $1.36 \mathrm{E}+12$ & $9.72 \mathrm{E}+11$ & $6.31 \mathrm{E}+11$ & $1.93 \mathrm{E}+11$ \\
\hline $\mathrm{R}_{\text {rev }}\left(\mathrm{m}^{-1}\right)$ & $1.80 \mathrm{E}+13$ & $1.84 \mathrm{E}+13$ & $1.51 \mathrm{E}+13$ & $2.01 \mathrm{E}+13$ & $1.82 \mathrm{E}+13$ & $1.53 \mathrm{E}+13$ \\
\hline
\end{tabular}

It can also be observed that the highest contribution to the total resistance is caused by the reversible membrane resistance in all the tests. That means that cake formation is the main mechanism involved in membrane fouling. Comparing both MBRs, the difference between the total resistances was due to the measured $R_{\text {rev }}$ values.

Figures 2 shows the permeate fluxes of the ultrafiltration experiments for mixed liquor samples from MBR-LS and MBR-HS, respectively. 


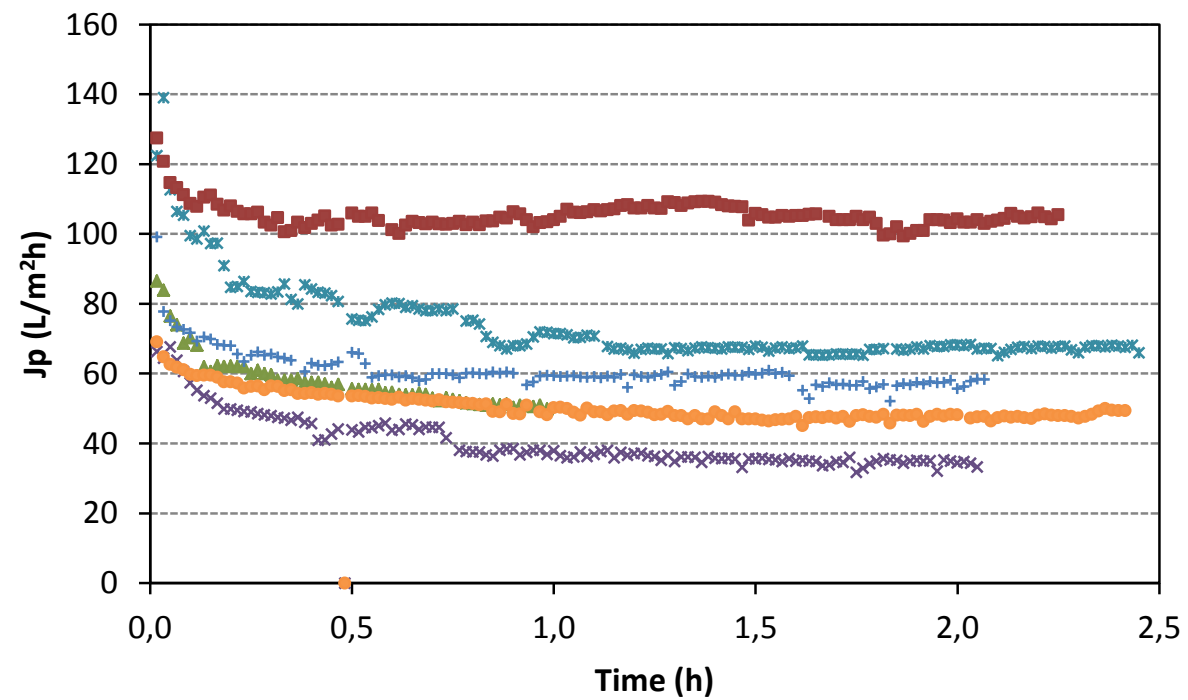

+ S1 MBR-HS - S2 MBR-HS • S3 MBR-HS $\backsim$ S4 MBR-HS • S5 MBR-HS * S6 MBR-HS

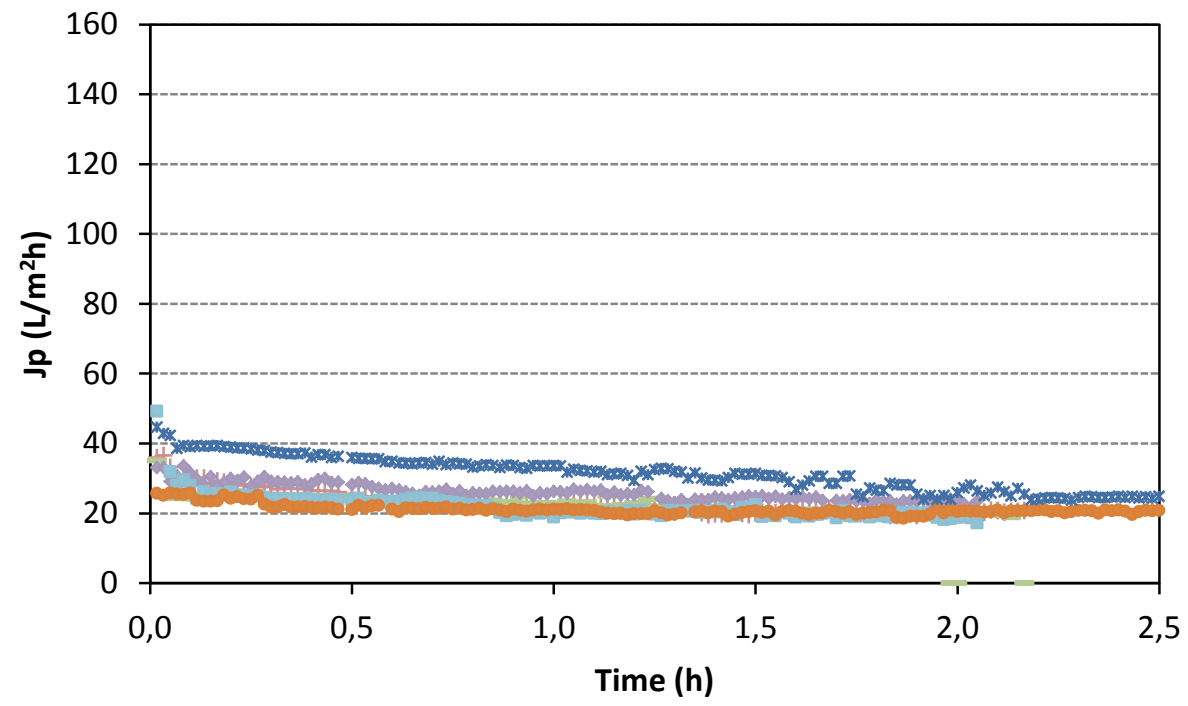

Figure 2. UF laboratory tests: Evolution of permeate flux using mixed liquor samples from MBR-LS (Fig. 2a) and MBR-HS (Fig. 2b) as feed (TMP $=1$ bar, T $=25^{\circ} \mathrm{C}, \mathrm{v}=2$ $\mathrm{m} / \mathrm{s})$

It can be observed that samples from MBR-HS showed much lower filterability than samples from MBR-LS. In fact, in the case of MBR-HS only for S6 it was achieved a flux higher than $25 \mathrm{~L} /\left(\mathrm{m}^{2} \cdot \mathrm{h}\right)$, which is lower than the minimum flux obtained in the UF of samples from MBR-LS. The reason for this behaviour will be discussed in the next 
paragraphs once the physical and chemical characterizations of the mixed liquors are detailed.

\section{$\underline{\text { Respirometric tests }}$}

Respirometric tests help determining the non-biodegradable organic fractions, which will remain in the bacterial flocs until they are taken out of the system in the sludge withdrawals. In the meanwhile, these fractions will collaborate to diminish the filterability of the mixed liquor contributing to the membrane fouling at the same time. In fact, though direct UF/MF of digestate liquor has been hardly studied, CamilleriRumbau et al., 2014 reported very low fluxes in the MF (0.2 microns of pore size) of digestate liquor from an anaerobic digester treating $50 \%$ of pig slurry, $15 \%$ of cattle manure, $10 \%$ chicken manure and $25 \%$ food waste. That is, fluxes were very similar to those obtained for the mixed liquor of MBR-HS. In general, it was observed that the more the SS in the influent is, the lower flux will be obtained in the UF of the mixed liquor. Table 5 shows the differences in the particulate non-biodegradable COD of both influents to MBRs.

The heterotrophic biomass yield coefficient $\left(\mathrm{Y}_{\mathrm{H}}\right)$ calculated according to Eq. 6, was 0.674 and 0.71 for MBR-LS and MBR-HS, respectively. These values showed that the microorganisms exhibit optimal growth when a rapidly biodegradable substrate is added, in both activated sludges.

In the MBR-HS observed in Table 5, total and soluble COD values measured spectrophotometrically were 70000 and $10400 \mathrm{mg} / \mathrm{L}$, respectively. As the soluble spectrophotometrically COD was very similar to the respirometric COD, it can be stated that the great majority of soluble COD was rapidly biodegradable. However, the inert particulate COD (difference between total and soluble inert COD) was very high. When results are compared with those obtained for the MBR-LS, it can be observed that inert particulate COD in MBR-HS was considerably higher than in MBR-LS. This can explain the differences in the mixed liquors in terms of physical properties and structure, and consequently the differences in filterability. 
Table 5: COD fractionation obtained with the respirometric tests (S3)

\begin{tabular}{c|cc}
\hline & MBR-LS $(\mathbf{m g} / \mathbf{L})$ & MBR-HS $(\mathbf{m g} / \mathbf{L})$ \\
\hline spCOD $^{\mathbf{1}}$ & & \\
\hline Total & 6580 & 70000 \\
Soluble & 2930 & 10400 \\
\hline rCOD $^{2}$ & & 64088 \\
\hline Total & 4854 & 10328 \\
\hline Soluble & 1931 & 5912 \\
\hline Inert calculated COD & & 72 \\
\hline Total & 1526 & \\
\hline Soluble & 999 & \\
\hline
\end{tabular}

Physical characterization and influence on mixed liquor filterability

MLSS and MLVSS concentrations

Table 6 shows the MLSS and MLVSS concentrations determined in the mixed liquor samples for each MBR.

Table 6. Total and volatile suspended solids concentration in MBR-LS and MBR-HS mixed liquors

\begin{tabular}{c|ccc|ccc} 
& \multicolumn{3}{|c|}{ MBR-LS } & \multicolumn{3}{c}{ MBR-HS } \\
\cline { 2 - 7 } & MLSS & MLVSS & $\%$ \%SS & MLSS & MLVSS & $\%$ \\
& $(g / L)$ & $(g / L)$ & & $(g / L)$ & $(g / L)$ & \\
\hline$S 1$ & 27.83 & 18.81 & 67.57 & 25.23 & 14.63 & 57.92 \\
$S 2$ & 13.06 & 10.07 & 77.15 & 26.59 & 16.79 & 63.63 \\
$S 3$ & 17.17 & 13.13 & 76.45 & 20.06 & 14.63 & 72.97 \\
$S 4$ & 19.38 & 15.10 & 77.90 & 21.67 & 16.69 & 77.02 \\
$S 5$ & 22.53 & 18.05 & 80.73 & 24.14 & 18.61 & 77.09 \\
S6 & 23.62 & 18.68 & 79.14 & 20.83 & 15.50 & 74.42 \\
\hline
\end{tabular}


As observed in Table 6, MLSS concentrations were variable in the period studied, mainly in MBR-LS. Values ranged between 13.06 and $27.83 \mathrm{~g} / \mathrm{L}$ for MBR-LS and between 20.06 and 26.59 for MBR-HS. These values can be considered typical for a recirculated MBR configuration, meanwhile a range between 8 and $18 \mathrm{~g} / \mathrm{L}$ is typical for submerged MBRs (Drews, 2010). The high concentrations are required to eliminate the degradable COD.

Concerning the percentage of volatile solids, Table 6 shows that the initial values (S1, S2 and S3) were the lowest ones. However, the MLVSS percentage increased when MLSS diminished due to the sludge withdrawals. Thus, values between 74 and $80 \%$ were reached.

On the other side, no relation between MLSS and sludge filterability was found. Thus, the maximum fluxes were obtained with S6 both in MBR-LS $\left(104 \mathrm{~L} / \mathrm{m}^{2} \cdot \mathrm{h}\right)$ and also in MBR-HS $\left(24.6 \mathrm{~L} / \mathrm{m}^{2} \cdot \mathrm{h}\right)$, corresponding to concentrations of MLSS of 23.62 and 20.83, respectively. These lack of relation between filterability and MLSS have been reported for submerged MBRs treating municipal wastewater (Lousada-Ferreira et al., 2015).

\section{Capillary suction time}

Capillary suction time (CST) was measured to evaluate the mixed liquor dewatering capacity by filtration. Results showed that activated sludge from MBR-HS was less dehydratable than the MBR-LS one, since CST values were very high (1629 s as average value) in comparison with MBR-LS sludge (83.5 s). This difference can be probably attributed to the considerable higher concentration of $\mathrm{SMP}_{\mathrm{C}}$ in MBR-HS than in MBR-LS. These positive correlations between CST and $\mathrm{SMP}_{\mathrm{c}}$ have been reported by (Reid et al., 2008; Sabia et al., 2013).

In addition,the mixed liquor with higher CST (MBR-HS) coincides with the mixed liquor that more resistance to filtration $\left(\mathrm{R}_{\mathrm{t}}\right)$ has (data collected in Table 4). 
Viscosity

The activated sludge is a non-Newtonian fluid with a pseudo-plastic behaviour (Moreau et al., 2009). Figure 3 shows the variation of the apparent viscosity $(\eta)$ and the shear stress $(\tau)$ with the shear rate $(\dot{\gamma})$ for the sample 2 from both MBRs.

The evolution of these rheological parameters was modelled using the Ostwald de Waele model (solid line), where $\tau$ (shear stress) can be expressed as a function of $\dot{\gamma}$, (shear rate) $\tau=K \cdot \dot{\gamma}^{n}$ and the apparent viscosity as $\eta=K \cdot \dot{\gamma}^{n-1}$, where the parameters $\mathrm{K}$ and $\mathrm{n}$ are the consistency index and flow behaviour index, respectively. For MBR-LS sample, the adjustment has been performed from 0 to $540 \mathrm{~s}^{-1}$, since from this shear rate on, the excessive turbulence was generatedd and Taylor vortices appear (Ratkovich et al., 2013).

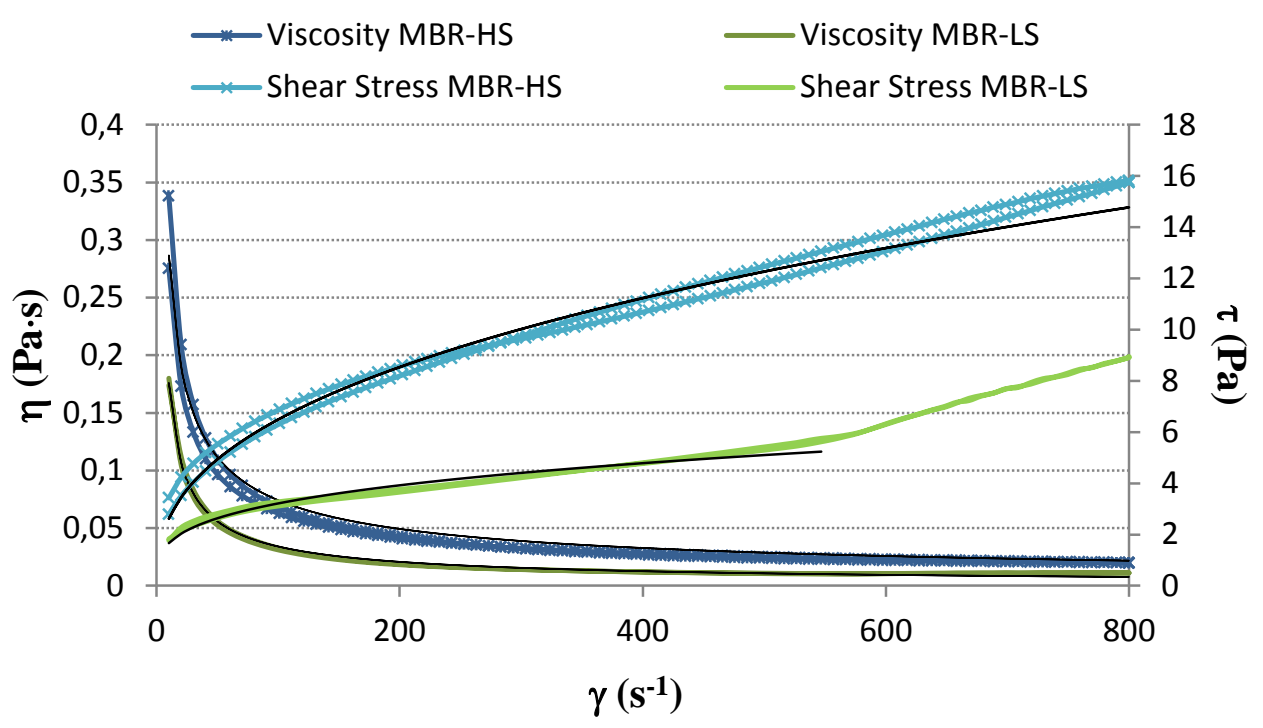

Figure 3: Comparison between apparent viscosities of the mixed liquors (S2) from both MBRs

It can be observed that the apparent viscosity in the mixed liquor from MBR-HS was considerable higher than the MBR-LS one, which could explain its lower filterability. This behaviour was very similar in all the analysed samples (S1-S6). However, slightly differences were observed with the MLSS.

\section{Chemical characterization and influence on mixed liquor filterability}

Figure4 show the protein and carbohydrate concentrations in SMP from both MBRs mixed liquors. 

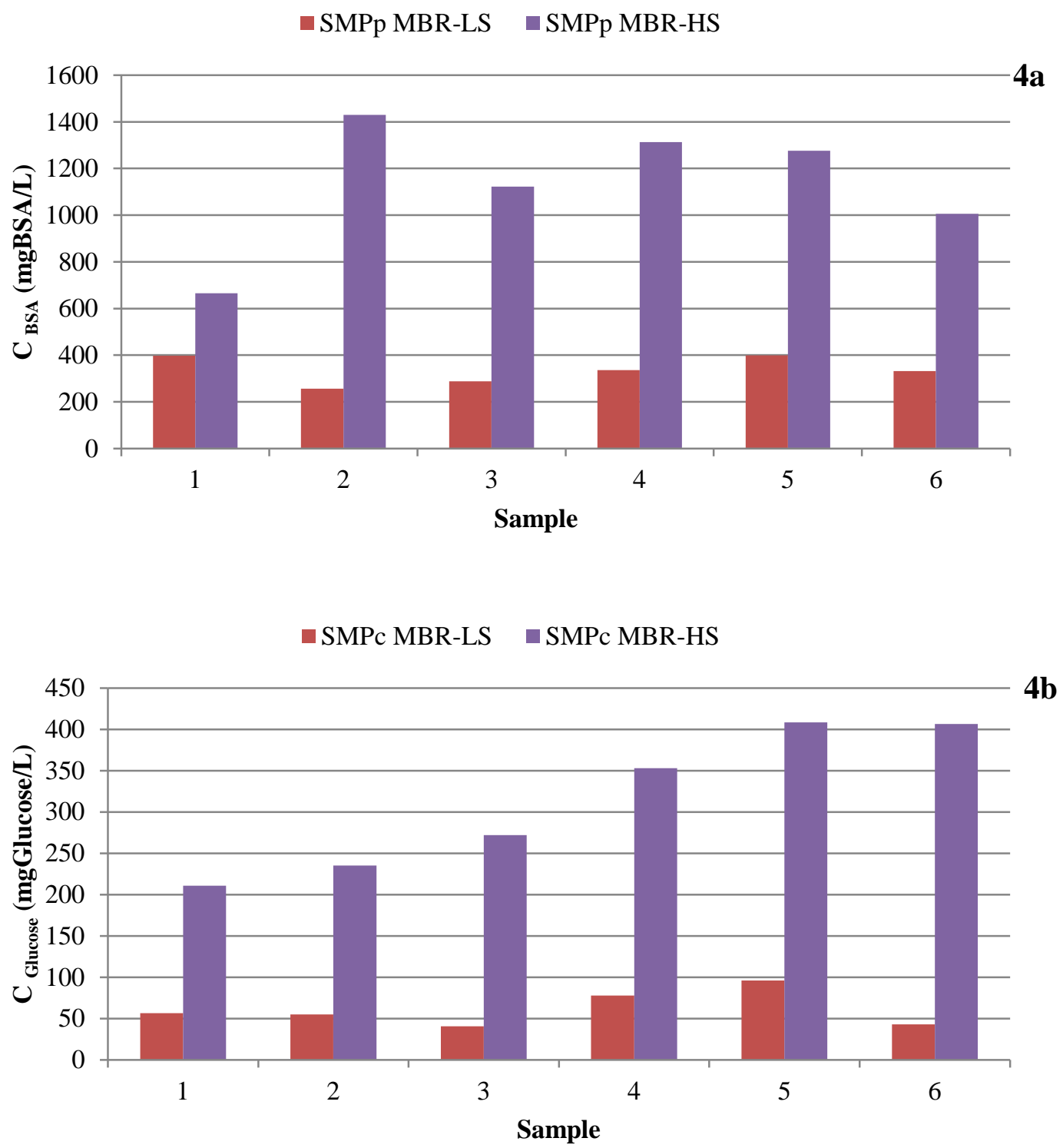

Figure 4. Protein (Fig. 4a) and carbohydrate (Fig. 4b) concentration in SMP from both MBRs mixed liquors

It can be observed clearly that SMP (both proteins and carbohydrates) concentration was higher in MBR-HS than in MBR-LS. This fact can be mainly due to the higher stress of the biomass in MBR-HS, caused by accumulation of non-biodegradable solids (Hao et al., 2010) and high salinity (40.13 $\pm 4.65 \mathrm{mS} / \mathrm{cm})$ (Jang et al., 2013) that can lead to bacteria stress.

These different values of SMP were considerably amplified from S2, what coincides with a pronounced increment of the VSS percentage in MBR-HS. Thus, S1 showed the lowest differences in SMPs between mixed liquors. In that sample, biomass in MBR-HS 
was considerably mineralized (only $57.92 \%$ of MLVSS). It can probably explain the lower SMP concentration by cryptic growth phenomena. It means that bacteria, in absence of degradable food or stress conditions, are able to use the residual cellular material as food, i.e. SMPp and SMPc. Once organic load is increased by sludge withdrawal, bacteria have more food available, the percentage of volatile solids increases and bacteria do not degrade the SMP.

The higher concentration of SMP in MBR-HS in comparison with MBR-LS and the influent wastewater composition are the causes that would explain the poor filterability of the mixed liquor samples from MBR-HS. In fact, the high SMP concentrations in MBR-HS samples do not allow appreciating differences among the fluxes obtained in the filterability tests. Nevertheless, it seems that there is a relationship between $\mathrm{SMP}_{\mathrm{C}}$ concentrations and UF fluxes represented in Figure 2 in MBR-LS samples. In fact, samples with the lowest SMPc concentrations (3 and 6) corresponded with the samples with the highest flux values in the filterability tests.

If these SMP concentrations are compared with those determined by other authors for MBRs treating landfill leachates, it can be mentioned that Sanguanpak et al., (2015) reported concentrations lower than the SMP obtained in MBR-LS. In fact, the SMPp concentrations measured in MBR-LS are around twice higher than those reported by these authors. For SMPc the relationship was very similar.

From Figure 4, it has to be highlighted that the concentration difference between proteins and carbohydrates is very high. Sabia et al., 2013 reported that ratio SMPp/SMPc sharply increased with the sludge retention time (SRT). In fact, SMPc were higher than SMPp for low SRT, whereas at high SRT the ratio SMPp/SMPc reached values between 5 and 10. These results are in agreement with those obtained in MBR-LS and MBR-HS, since both hydraulic and sludge retention times are high in order to achieve the required COD removal efficiencies.

The mechanism that may cause this behaviour could be associated to the appearance of microorganisms that degrade in a higher extent carbohydrates coming from cellular debris. 
As shown in Figure 5, the abundance of filamentous bacteria belonging to the Bacteroidetes phylum was very high. Among them, Haliscomenobacter filaments were observed as predominant ones.
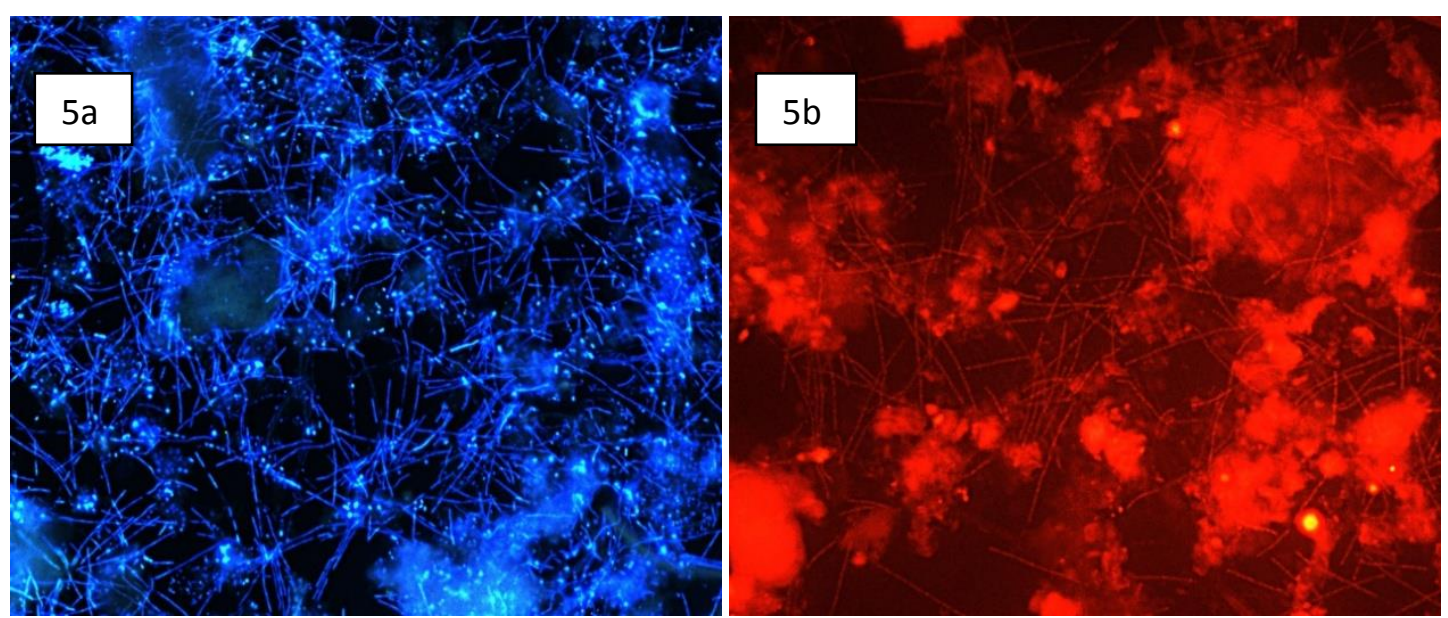

Figure 5. (Fig. 5a) Filaments with a needle-like appearance similar to

Haliscomenobacter DAPI staining. (Fig. 5b) Haliscomenobacter filaments identified with the probe SAP-309 using FISH technique (S3, MBR-HS)

Haliscomenobacter filaments are specialized bacteria involved in degradation of sugars, e.g. glucose and $\mathrm{N}$-acetylglucosamine, and may participate in the conversion of lipopolysaccharides and peptidoglycan liberated by decaying cells (Kragelund et al., 2008). Therefore, these bacteria are able to degrade carbohydrates, increasing the relationship between proteins and carbohydrates concentration.

Figure 6 shows the protein $(\mathrm{P})$ and carbohydrate $(\mathrm{C})$ concentrations in eEPS from both MBRs mixed liquors. 


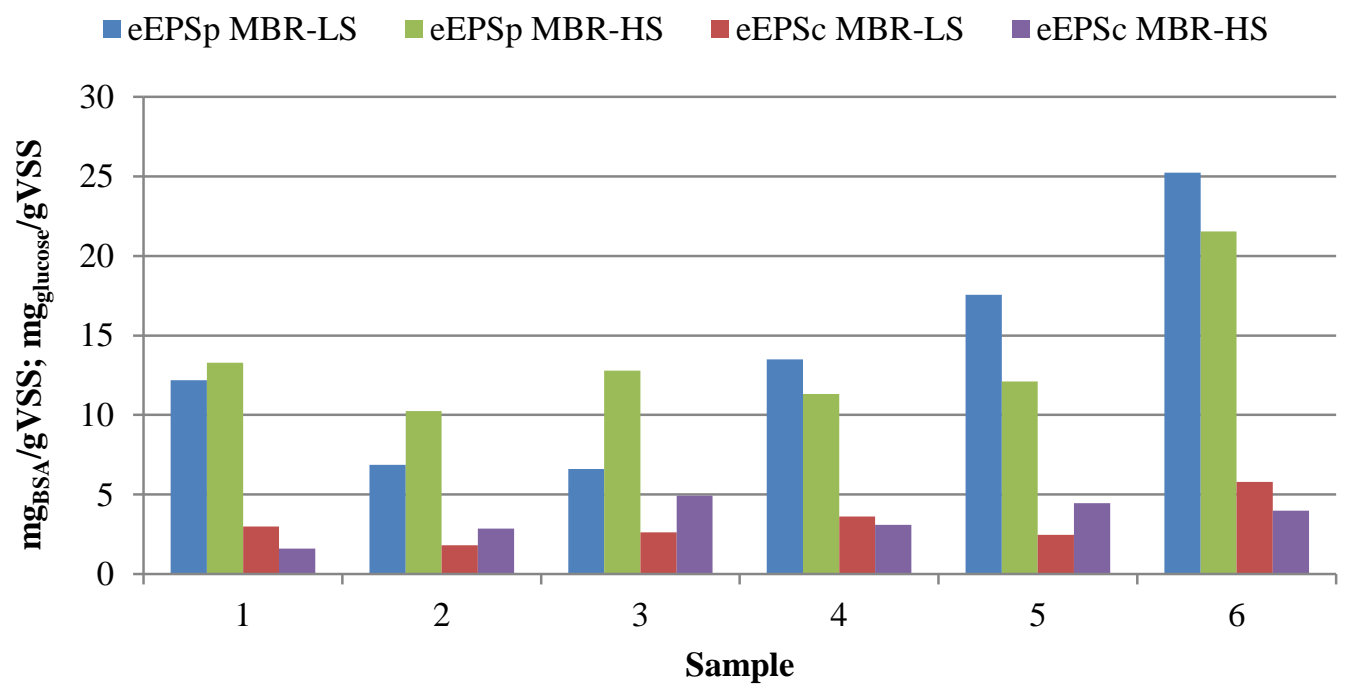

Figure 6. Protein and carbohydrate concentration in eEPS from both MBRs mixed liquors

Unlike SMPs, differences between eEPS from both MBRs mixed liquors were not found; thereby we can state that this parameter was not responsible for the different behaviour of the mixed liquors in the UF tests. Compared to the concentrations reported by Sanguanpak et al. (2015), the measured eEPS concentrations were lower. It is probably due to the low organic matter concentration available for the microorganisms in MBR-LS and MBR-HS. They assimilate rapidly the degradable organic matter adsorbed on the bacterial flocs.

Summarizing, the mixed liquors of MBR-LS and MBR-HS are characterized by high amounts of cellular debris that are responsible for the high SMP concentrations (especially in MBR-HS). This has no influence on the eEPS concentration, which is low and very similar in both MBRs due to the low organic loads and the lack of organic matter available for the microorganisms.

\section{Conclusions}

In this study, the mixed liquor characteristics of two full-scale MBRs treating effluents from OFMSW management plants have been compared. It can be concluded that the plant that uses high solids anaerobic digestion generates effluents with higher SS and conductivity than the plant with low solids anaerobic digestion. Thus, influent 
characteristics were the most important factor influencing the mixed liquor filterability. The low filterability of the MBR-HS mixed liquor is explained mainly by the high viscosity, considerable higher than that measured for the mixed liquor of MBR-LS. Besides, biomass of MBR-HS is subjected to more stress than biomass of MBR-LS due to high non-biodegradable suspended solids concentration and salinity; whereby SMPs concentrations were higher than in MBR-LS. No differences between extracted EPS were detected.

As a general conclusion, and on the basis of the results obtained, a lower design flux should be considered for this type of plants, since fouling problems occur mainly due to the influent MBR characteristics and SMPs generated by bacteria of the mixed liquor.

\section{Acknowledgements}

This work was supported by the URBASER Company. Authors thank personnel of the full-scale MBR plants for providing samples.

\section{Bibliography}

Ahmed, F.N., Lan, C.Q., 2012. Treatment of landfill leachate using membrane bioreactors: A review. Desalination 287, 41-54.

Alvarez-Vazquez, H., Jefferson, B., Judd, S.J., 2004. Membrane bioreactors vs conventional biological treatment of landfill leachate: a brief review. J. Chem. Technol. Biotechnol. 79, 1043-1049.

APHA, 2005. Standard methods for the examination of water and wastewater, 21sti ed. American Public Health Association, Washington DC.

Bae, T.-H., Tak, T.-M., 2005. Interpretation of fouling characteristics of ultrafiltration membranes during the filtration of membrane bioreactor mixed liquor. J. Memb. Sci. 264, 151-160.

Boonyaroj, V., Chiemchaisri, C., Chiemchaisri, W., Theepharaksapan, S., Yamamoto, K., 2012. Toxic organic micro-pollutants removal mechanisms in long-term operated membrane bioreactor treating municipal solid waste leachate. Bioresour. Technol. 113, 174-80.

Brown, K., Ghoshdastidar, A.J., Hanmore, J., Frazee, J., Tong, A.Z., 2013. Membrane 
bioreactor technology: a novel approach to the treatment of compost leachate. Waste Manag. 33, 2188-94.

Camilleri-Rumbau, M.S., Norddahl, B., Wei, J., Christensen, K.V., Søtoft, L.F., 2014. Microfiltration and ultrafiltration as a post-treatment of biogas plant digestates for producing concentrated fertilizers. Desalin. Water Treat. 55, 1639-1653.

Campagna, M., Cakmakc1, M., Yaman, F.B., Ozkaya, B., 2013. Molecular weight distribution of a full-scale landfill leachate treatment by membrane bioreactor and nanofiltration membrane. Waste Manag. 33, 866-70.

Canziani, R., Emondi, V., Garavaglia, M., Malpei, F., Pasinetti, E., Buttiglieri, G., 2006. Effect of oxygen concentration on biological nitrification and microbial kinetics in a cross-flow membrane bioreactor (MBR) and moving-bed biofilm reactor (MBBR) treating old landfill leachate. J. Memb. Sci. 286, 202-212.

Cesaro, A., Russo, L., Belgiorno, V., 2015. Combined anaerobic/aerobic treatment of OFMSW: Performance evaluation using mass balances. Chem. Eng. J. 267, 16-24.

Ding, Y., Tian, Y., Li, Z., Zuo, W., Zhang, J., 2015. A comprehensive study into fouling properties of extracellular polymeric substance (EPS) extracted from bulk sludge and cake sludge in a mesophilic anaerobic membrane bioreactor. Bioresour. Technol. 192, 105-14.

Drews, A., 2010. Membrane fouling in membrane bioreactors-Characterisation, contradictions, cause and cures. J. Memb. Sci. 363, 1-28.

Frølund, B., Palmgren, R., Keiding, K., Nielsen, P.H., 1996. Extraction of extracellular polymers from activated sludge using a cation exchange resin. Water Res. 30, 1749-1758.

Hao, X.-D., Wang, Q.-L., Zhu, J.-Y., Van Loosdrecht, M.C.M., 2010. Microbiological Endogenous Processes in Biological Wastewater Treatment Systems. Crit. Rev. Environ. Sci. Technol. 40, 239-265.

Hasar, H., Ipek, U., Kinaci, C., 2009. Joint treatment of landfill leachate with municipal wastewater by submerged membrane bioreactor. Water Sci. Technol. 60, 31213127.

Hashisho, J., El-Fadel, M., Al-Hindi, M., Salam, D., Alameddine, I., 2016. Hollow fiber vs. flat sheet MBR for the treatment of high strength stabilized landfill leachate. 


\section{Waste Manag.}

Jang, D., Hwang, Y., Shin, H., Lee, W., 2013. Effects of salinity on the characteristics of biomass and membrane fouling in membrane bioreactors. Bioresour. Technol. $141,50-56$.

Judd, S., 2011. The MBR book: Principles and Applications of Membrane Bioreactors for Water and Wastewater Treatment. Elsevier Ltd.

Khongnakorn, W., Wisniewski, C., Pottier, L., Vachoud, L., 2007. Physical properties of activated sludge in a submerged membrane bioreactor and relation with membrane fouling. Sep. Purif. Technol. 55, 125-131.

Kragelund, C., Levantesi, C., Borger, A., Thelen, K., Eikelboom, D., Tandoi, V., Kong, Y., Krooneman, J., Larsen, P., Thomsen, T.R., Nielsen, P.H., 2008. Identity, abundance and ecophysiology of filamentous bacteria belonging to the Bacteroidetes present in activated sludge plants. Microbiology 154, 886-894.

Li, Y., Park, S.Y., Zhu, J., 2011. Solid-state anaerobic digestion for methane production from organic waste. Renew. Sustain. Energy Rev. 15, 821-826.

Lin, H., Gao, W., Meng, F., Liao, B.-Q., Leung, K.-T., Zhao, L., Chen, J., Hong, H., 2012. Membrane Bioreactors for Industrial Wastewater Treatment: A Critical Review. Crit. Rev. Environ. Sci. Technol. 42, 677-740.

Lin, H., Zhang, M., Wang, F., Meng, F., Liao, B.Q., Hong, H., Chen, J., Gao, W., 2014. A critical review of extracellular polymeric substances (EPSs) in membrane bioreactors: Characteristics, roles in membrane fouling and control strategies. J. Memb. Sci. 460, 110-125.

Litas, G.C., Zouboulis, A.I., Zaboulis, D., Samaras, P., 2012. The use of a submerged membrane batch reactor (SMBR) for co-treatment of landfill leachates and domestic wastewater. Desalin. Water Treat. 39, 284-290.

Liu, Y., Liu, Z., Zhang, A., Chen, Y., Wang, X., 2012. The role of EPS concentration on membrane fouling control: Comparison analysis of hybrid membrane bioreactor and conventional membrane bioreactor. Desalination 305, 38-43.

Lousada-Ferreira, M., van Lier, J.B., van der Graaf, J.H.J.M., 2015. Impact of suspended solids concentration on sludge filterability in full-scale membrane bioreactors. J. Memb. Sci. 476, 68-75. 
Lyko, S., Wintgens, T., Alhalbouni, D., Baumgarten, S., Tacke, D., Drensla, K., Janot, A., Dott, W., Pinnekamp, J., Melin, T., 2008. Long-term monitoring of a full-scale municipal membrane bioreactor-Characterisation of foulants and operational performance. J. Memb. Sci. 317, 78-87.

Meng, F., Chae, S.R., Drews, A., Kraume, M., Shin, H.S., Yang, F., 2009. Recent advances in membrane bioreactors (MBRs): Membrane fouling and membrane material. Water Res. 43, 1489-1512.

Moreau, A.A., Ratkovich, N., Nopens, I., van der Graaf, J.H.J.M., 2009. The (in)significance of apparent viscosity in full-scale municipal membrane bioreactors. J. Memb. Sci. 340, 249-256.

Nghiem, L.D., Tadkaew, N., Sivakumar, M., 2009. Removal of trace organic contaminants by submerged membrane bioreactors. Desalination 236, 127-134.

Omar, H., Rohani, S., 2015. Treatment of landfill waste, leachate and landfill gas: A review. Front. Chem. Sci. Eng. 9, 15-32.

Pokhrel, D., Viraraghavan, T., 2004. Leachate generation and treatment - A review. Fresenius Environ. Bull.

Ras, M., Girbal-Neuhauser, E., Paul, E., Spérandio, M., Lefebvre, D., 2008. Protein extraction from activated sludge: an analytical approach. Water Res. 42, 1867-78.

Ratkovich, N., Horn, W., Helmus, F.P., Rosenberger, S., Naessens, W., Nopens, I., Bentzen, T.R., 2013. Activated sludge rheology: A critical review on data collection and modelling. Water Res. 47, 463-482.

Reid, E., Liu, X., Judd, S.J., 2008. Sludge characteristics and membrane fouling in fullscale submerged membrane bioreactors. Desalination 219, 240-249.

Renou, S., Givaudan, J.G., Poulain, S., Dirassouyan, F., Moulin, P., 2008. Landfill leachate treatment: Review and opportunity. J. Hazard. Mater. 150, 468-93.

Rizkallah, M., El-Fadel, M., Saikaly, P.E., Ayoub, G.M., Darwiche, N., Hashisho, J., 2013. Hollow-fiber membrane bioreactor for the treatment of high-strength landfill leachate. Waste Manag. Res. 31, 1041-1051.

Rossetti S., Blackall L., Tandoi V., 2006. The microbiology of activated sludge. In Activated Sludge separation Problems. IWA Publishing Scientific and Technical Report, London. 
Sabia, G., Ferraris, M., Spagni, A., 2013. Effect of solid retention time on sludge filterability and biomass activity: Long-term experiment on a pilot-scale membrane bioreactor treating municipal wastewater. Chem. Eng. J. 221, 176-184.

Sanguanpak, S., Chiemchaisri, C., Chiemchaisri, W., Yamamoto, K., 2015. Influence of operating $\mathrm{pH}$ on biodegradation performance and fouling propensity in membrane bioreactors for landfill leachate treatment. Int. Biodeterior. Biodegradation 102, 64-72.

Schauer, M., Hahn, M.W., 2005. Diversity and Phylogenetic Affiliations of Morphologically Conspicuous Large Filamentous Bacteria Occurring in the Pelagic Zones of a Broad Spectrum of Freshwater Habitats. Appl. Environ. Microbiol. 71, 1931-1940.

Svojitka, J., Wintgens, T., Melin, T., 2009. Treatment of landfill leachate in a bench scale MBR. Desalin. Water Treat. 9, 136-141.

Tampio, E., Ervasti, S., Rintala, J., 2015. Characteristics and agronomic usability of digestates from laboratory digesters treating food waste and autoclaved food waste. J. Clean. Prod. 94, 86-92.

Wang, Z., Wu, Z., Tang, S., 2009. Extracellular polymeric substances (EPS) properties and their effects on membrane fouling in a submerged membrane bioreactor. Water Res. 43, 2504-2512.

Wiszniowski, J., Robert, D., Surmacz-Gorska, J., Miksch, K., Weber, J. V., 2006. Landfill leachate treatment methods: A review. Environ. Chem. Lett. 4, 51-61. 